\title{
PERFORMANCE STATUS OF COMMON EFFLUENT TREATMENT PLANT AT DOMBIVALI CETP
}

\author{
Ketan A.Salunke ${ }^{1}$, Prashant.P.Bhave ${ }^{2}$, Manish D. Mata ${ }^{3}$ \\ ${ }^{1}$ Assistant professor., Civil Engineering Department, SIEM Nashik, Maharashtra, India \\ ${ }^{2}$ Associate Professor, Department Civil and Environmental Engineering, V.J. Technological Institute, Matunga, \\ Mumbai 400019, India \\ ${ }^{3}$ Lecturer, Civil Engineering Department, MET BKC IOE Nashik, Maharashtra, India
}

\begin{abstract}
The aim of this study is to evaluate the performance of common effluent treatment plant situated in the MIDC area of Dombivali. The Dombivali (Phase-II) has capacity of 1.5 MLD. These plants majorly treat effluent from chemicals and engineering industries. Water samples were collected at influent and effluent of treatment plant and analyzed for the major water quality parameters viz. pH, biological oxygen demand (BOD), chemical oxygen demand (COD), total suspended solids (TSS) and total dissolved solids (TDS). The overall performance of treatment plant was calculated. The generated data shows that CETP has been working with the norms of Central Pollution Control Board and meeting the discharge standard limits.
\end{abstract}

Keywords: CETP, discharge standards, effluent, pollution.

\section{INTRODUCTION}

Protection of water environment calls for waste treatment before its disposal into inland water bodies or as land irrigation. Secondly, water is a precious commodity and therefore must be conserved. In view of this it is necessary to treat wastewater for reusing or recycling it[1]. Both types of wastewater viz. municipal sewage and industrial waste water need to be treated so as to confirm the discharge conditions as stipulated in consent given by Central or State Pollution Control Board. Bulk of the industrial pollution in India results from small scale industries. The large-scale industries generally have their own treatment plants. If not, they at least do not have financial, manpower and land availability constraints for installation and maintenance of the treatment plants. A common effluent treatment plant serves many industries mostly small and medium scale industries.[5] In a common effluent treatment plant, the effluents from the different industries are treated using one universal treatment system. Common effluent treatment plants eliminate duplicity of treatment systems among the industries on the industrial estate and hence results in a reduction in the total capital required for construction of the industrial estate.[10] Common effluent treatment plants also allow better monitoring and control of effluent quality. In some cases, wastewater from some industries may require pretreatment before it is allowed to enter may enter the common effluent treatment plant. This may be necessary because of a high pollution concentration produced by a specific industry or perhaps the presence of a specific group of toxins not treated by the common effluent plant.

Dombivali Common Effluent Treatment Plant is a public limited company formed by chemical industry members of industrial association with the help of Maharashtra Pollution Control Board(MPCB) and MIDC. This company was formed basically to treat the wastewater from its member industries to the standards laid down by MPCB for discharge into the nallah, which joins to the saline zone of Ulhas river basin. Dombivali CETP( Phase-II) has started operation in May 1999 and has capacity to treat 1.5MLD of effluent per day. The total cost of the project is about 260 lacs.

The present investigation has been undertaken as a case study in the evaluation of overall performance of CETP functioning at M.I.D.C. Dombivali.

\section{MATERIALS AND METHODS}

Samples were collected from the two sampling locations i.e. from the influent and effluent of the plant. Before collection of samples containers were rinsed with the samples being collected. Grab type sampling technique was used to collect the samples. Collected samples were analyzed for the parameters $\mathrm{pH}, \mathrm{BOD}, \mathrm{COD}$, TSS, and TDS. As possible samples were analyzed on the same day whenever it was possible; otherwise these samples were preserved at $4 \mathrm{oC}$. Analysis was done in the laboratory by determining various parameters according to "standards methods for examination of water and waste water". [9]

\section{TREATMENT UNITS}

Following treatment units are provided in CETP for the treatment of industrial effluent.

\subsection{Primary Treatment}

\subsubsection{Collection of Raw Effluent}

Raw effluent from MIDC collection sump is pumped to equalization cum neutralization tank with the help of raw 
effluent transfer pump. Then air blower is started to aerate and mix the contents of equalization tank when raw effluent is being taken. $\mathrm{pH}$ is checked during mixing.

\subsubsection{Neutralization of Raw Effluent}

Contents of the filled equalization tank are tested for $\mathrm{pH}$. A lime slurry is prepared in lime tank is then drained by the equalization tank effluent while under mixing with aeration to neutralize. The $\mathrm{pH}$ is bought to approximately 7.0 (between $6.0 \& 8.0$ ). The contents of equalization tank are continued under mixing for further 30 minutes.

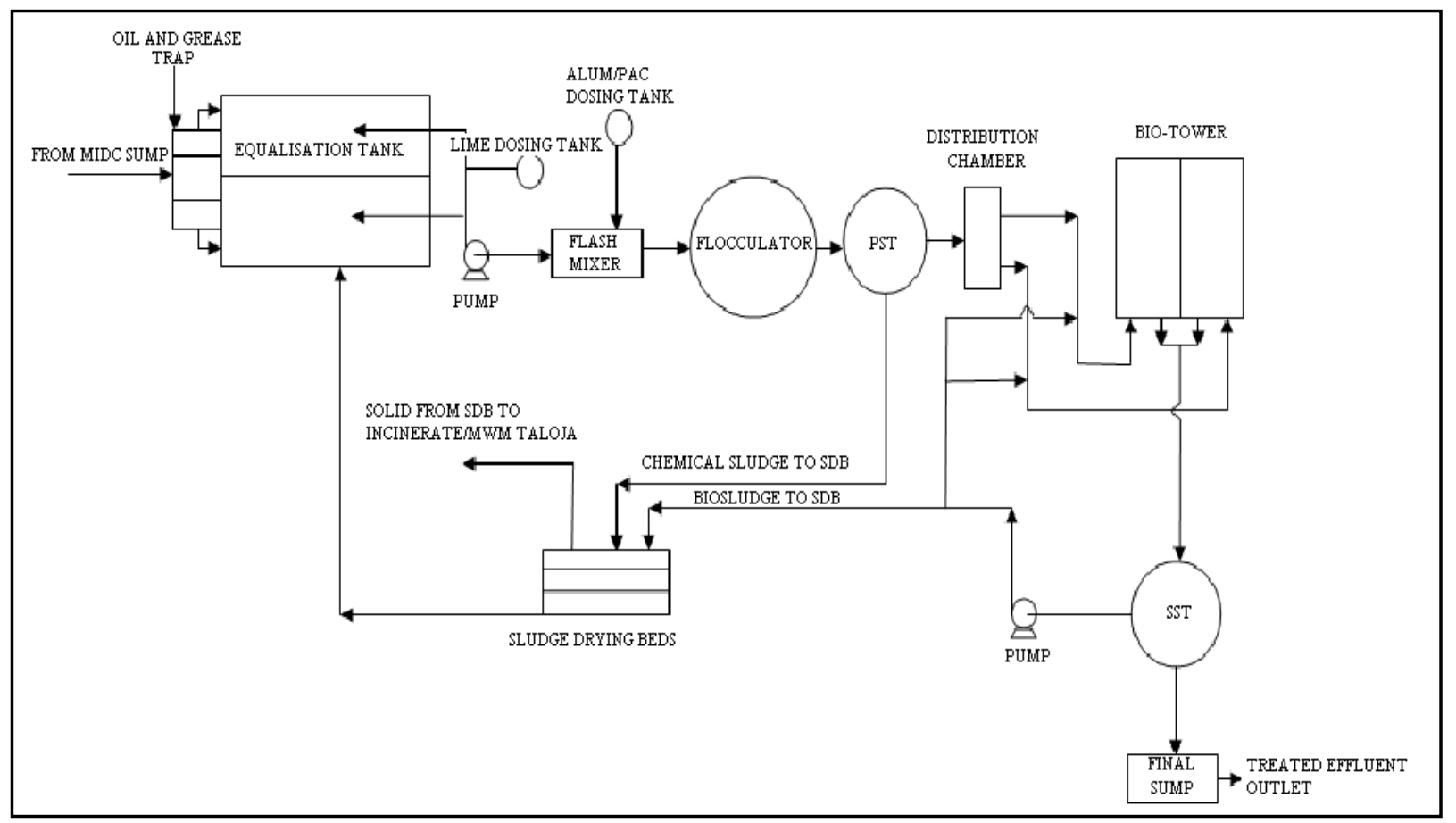

Fig.3.1: Flow diagram showing units and processes in Dombivali CETP

\subsubsection{Primary Clarification}

Neutral contents of equalization tank which are under aeration or mixing are pumped with one of the feed pumps to flash mixer through floculator continuously. Alum or polyelectrolyte solution is dosed from the tank continuously at a predetermined rate. Contents of the flash mixer are allowed to further flow to floculator. Suspended solids are allowed to form flocs to facilitate settling in primary settling tank. Contents of floculator, with flocs of suspended solids are further flown to primary settling tank. With the help of sludge scrapping mechanism in the primary settling tank suspended solids flocs are settle down and clear effluent is further overflown to biotower sump for secondary treatment. Settled solids in the primary settling tank are removed by gravity through the bottom opening, in the form of slurry and are drained from time to time to one of the sludge drying beds. Solids area allowed to dry by solar evaporation. Dry solids are removed manually and filled in suitable containers for further disposal. Filtrate from the sludge drying beds is taken to equalization tank along with raw effluent for treatment. B.

\subsection{Secondary Treatment}

Effluent from primary settling tank is overflown to a distribution chamber in which two compartments are provided. Outlets of these two compartments are fitted with $\mathrm{V}$-notches. Effluent through the distribution chamber is flown to two biotower sumps is such proportion that flow to two biotower sumps in such a proportion that flow to biotower $\mathrm{A}$ is double that of biotower $\mathrm{B}$ as number of packing provided in A are double that of B. Effluent from sump is pumped through the top grid of biotower with the help of circulation pumps. Effluent from top grid of biotower is allowed to flow through the packings in the tower which is coated with activated biomass. Thus effluent comes in contact with biomass and while travelling from top to bottom by gravity through the zigzag way picks up oxygen from the atmosphere. These two processes helps to oxidize dissolved organics from the effluent thereby bringing down BOD/COD values to desired levels. Effluent from the bottom of biotower which has less BOD/COD levels contain some biosolids. These biosolids are allowed to settle in the secondary settling tank. Settled solids are then removed from the bottom of the settling tank with the help of pump and are sent to biotower sump. Clear effluent through the secondary settling tank is further discharged to MIDC designated disposal point. 
Table 1: Inlet and outlet characteristics for CETP

\begin{tabular}{|l|l|l|l|}
\hline Parameter & $\begin{array}{l}\text { Inlet } \\
\text { Characteristics }\end{array}$ & $\begin{array}{l}\text { Outlet } \\
\text { Characteristics }\end{array}$ & $\begin{array}{l}\text { Discharge } \\
\text { Limits }\end{array}$ \\
\hline pH & 5.5 to 7.5 & 7.0 to 7.5 & 5.5 to 9.0 \\
\hline TSS mg/l & 100 to 350 & 25 to 75 & 100 \\
\hline BOD mg/l & 200 to 500 & 10 to 50 & 100 \\
\hline COD mg/l & 900 to 1200 & 180 to 240 & 250 \\
\hline
\end{tabular}

\section{RESULTS AND DISCUSSION}

The main objective of present work is to evaluate integrated performance of common effluent treatment plant by studying influent and effluent characteristics of the plant. The effluent which is coming from the various industries contains high $\mathrm{pH}, \mathrm{COD}, \mathrm{BOD}$, TDS etc. An understanding of nature of waste water is essential in the design and operation of collection, treatment and disposal facilities. The results obtained in the present study after analyzing influent and effluent of CETP are discussed as follows.

\section{$4.1 \mathrm{pH}$}

Measurement of $\mathrm{pH}$ is one of the most important and frequently used tests in water chemistry. Determination of $\mathrm{pH}$ is one of the important objectives in treatment of waste water. [4]. $\mathrm{pH}$ of water drastically changes with time due to the exposure to air, biological activity and temperature changes. Significant changes in $\mathrm{pH}$ occur due to disposal of industrial waste. In natural waters $\mathrm{pH}$ changes due to variation in photosynthetic activity which increases the $\mathrm{pH}$ consumption of $\mathrm{CO} 2$ in the process. Most chemical and biological reactions occur at a narrow range of $\mathrm{pH}$.In anaerobic treatment if the $\mathrm{pH}$ goes below 5 due to excess accumulation of acids the process is severely affected. Shifting of $\mathrm{pH}$ beyond 5 to 10 upsets the aerobic treatment of waste. In these circumstances $\mathrm{pH}$ can be adjusted by addition of suitable acid or alkali to optimize the treatment of waste.

In the present study it is found that influent $\mathrm{pH}$ value for CETP is in between 7.5 to 9.0 while for the effluent the $\mathrm{pH}$ between 6.5 to 8.5 which is slightly fluctuating towards the alkaline side. The variation in the $\mathrm{pH}$ occurs due to the high degree of variability in the quality as well as variations in the flow rates of industrial waste. These values are within the limit (5.5 to 9.0) set up by pollution control board.

\subsection{Total Suspended Solids}

Many industrial operations contribute turbidity and settleable solids to water with resulting bottom deposits which affects aquatic life in varying severity. Fine particulate matter which remains in suspension can limit the penetration of light, thus restricts the growth of attached bottom aquatic plants as well as floating or weekly swimming algal forms which are photosynthetic organisms depending upon light for their existence. Also solids floc, planktonic algae and animals carry them to bottom where they die. Thus in limiting growth of aquatic plant medows, food chains is interrupted, resulting in sparity of animal life.
Deposits of settleable solids can blanket the substrate forming undesirable environment for the stream habitat organisms. Inorganic substances in higher concentration will be more severe in reducing aquatic populations than the resulting reaction in them by the settleable organic solids.[8] In the present study it is found that, for CETP influent TSS is in the range of 260 to $600 \mathrm{mg} / \mathrm{l}$, while for the effluent these value is in between 30 to $160 \mathrm{mg} / \mathrm{l}$. Fig. 2 shows the variation in TSS.

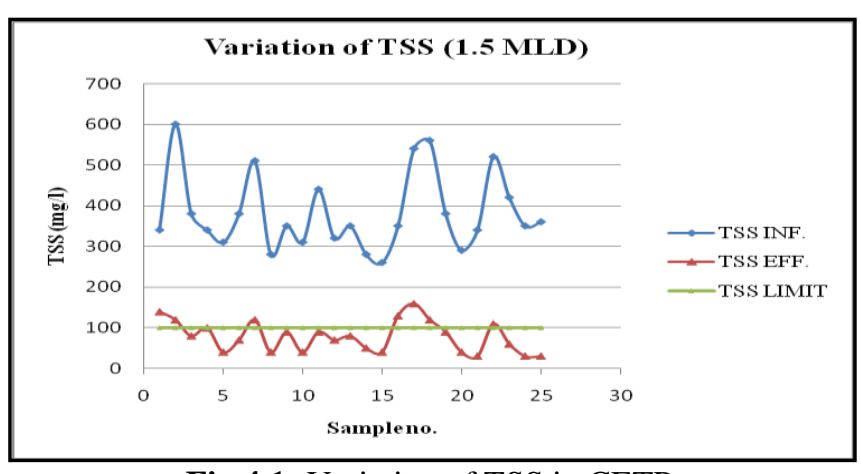

Fig.4.1: Variation of TSS in CETP

\subsection{Total Dissolved Solids}

High TDS in treated effluent is a widespread problem in many CETPs. It is observed that salinity, primarily due to salts of sodium, is the primary contributor to the high TDS problem as high TDS is almost invariably accompanied by high chlorides and sodium concentration.[6] The TDS concentration of the wastewater is mainly due to the inorganic ions in the water supply and those added during the use of water. In industries such as tanneries, pharmaceutical units, chemicals manufacturing units and dye and dye intermediate units, the high TDS in wastewater can be primarily attributed to addition during the use of water.[10] In such cases the best approach for reduction of TDS is to try reduction at source by adopting cleaner technologies for reduction of net input of chemicals, practicing recovery and recycling of chemicals. The chemical treatment adopted in the treatment scheme at CETP generally does not specifically aim at removing these ions. Therefore, reduction in the TDS concentration of the effluent during its treatment is not expected.

Here, CETP at is able to comply with the prescribed limit for TDS for the treated effluent.The TDS concentration in effluent in CETP is in the range of 710 to $1800 \mathrm{mg} / \mathrm{l}$.

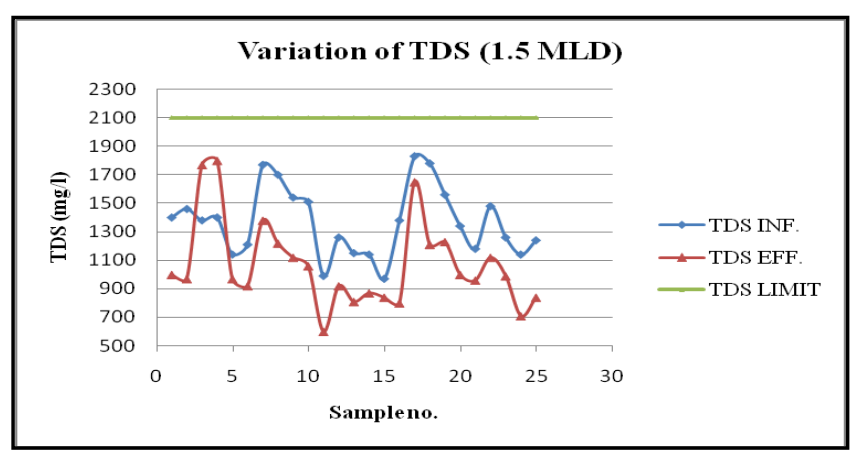

Fig.4.2: Variation of TDS in CETP 


\subsection{BOD}

The amount of oxygen required by the micribial activity to oxidise and stabilise the decomposable organic matter is called the biochemical oxygen demand .The biochemical oxygen demand (BOD) determination is an empirical test in which standardized laboratory procedures are used to determine relative oxygen requirements of wastewater. The test has widest application in measuring waste loading to treatment plants and evaluation of BOD removal efficiency of such treatment systemsThe test has its limitations but still used extensively and is useful for determining approximately how much oxygen will be removed from water by an effluent or how much may be required for treatment and to estimate size of the treatment plant needed. From the result it is found that,the influent from Dombivali CETP having BOD in the range of 290 to $510 \mathrm{mg} / \mathrm{l}$. For the effluent BOD value for CETP is in the range of 30 to 90 $\mathrm{mg} / \mathrm{l}$.If we consider inland surface water limit $(30 \mathrm{mg} / \mathrm{l})$ then both CETPs effluent BOD exceeds the limit but for other limits like discharge on land for irrigation and for discharge into marine coastal area $(100 \mathrm{mg} / \mathrm{l})$ these values are within limit.the graphical representation of BOD variation in CETPs is given below in Fig.4.and Fig.5.

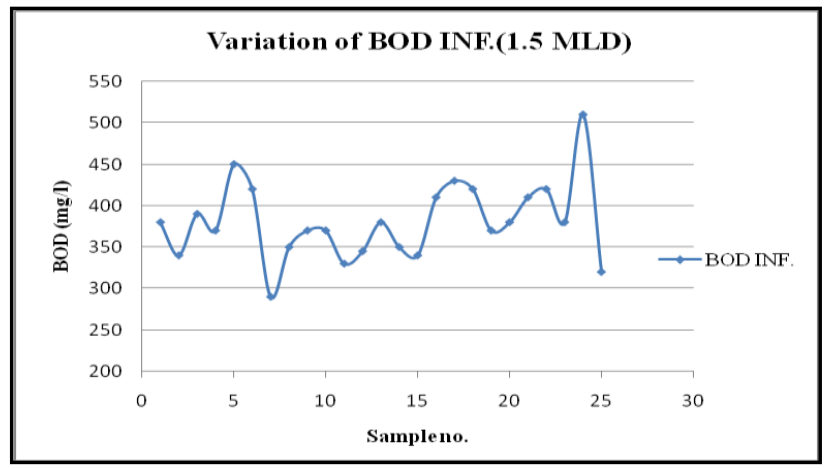

Fig.4.3: Variation of BOD at influent in CETP

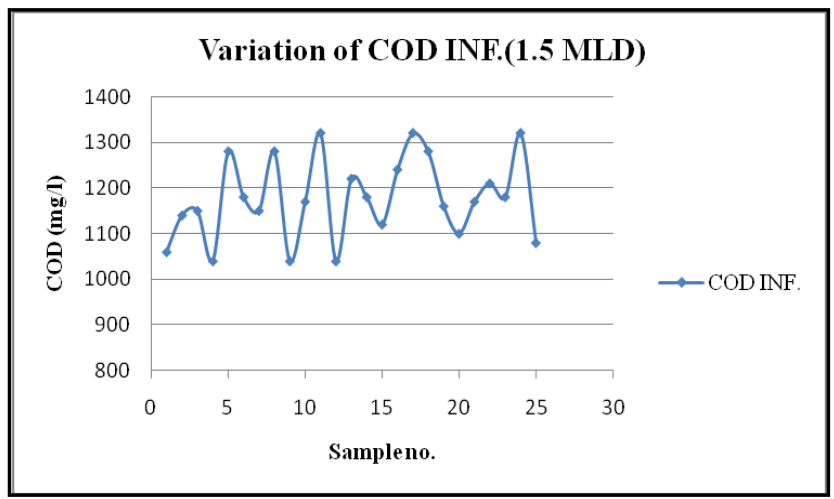

Fig.4.4: Variation of BOD at effluent in CETP

\subsection{COD}

The chemical oxygen demand (COD) is use as a measure of the oxygen equivalent of the organic matter content of a sample that is susceptible to oxidation by strong chemical oxidant. The COD test is used to measure the content of organic matter of both wastewater and natural water. The oxygen equivalent that can be oxidized is measured by using a strong chemical oxidizing agent such as potassium dichromate in an acidic medium. The COD test is also used to measure organic matter in industrial and municipal waste that contain compounds that are toxic to biological life. In general the COD of the waste is higher than BOD because more compounds can be chemically oxidized that can biologically oxidized.

In the present study, influent from CETP having COD is in the range of 1040 to $1320 \mathrm{mg} / \mathrm{l}$.The COD of effluent of CETP is between 190 to $340 \mathrm{mg} / \mathrm{l}$. The variation in COD is shown graphically in Fig.6 and Fig.7.

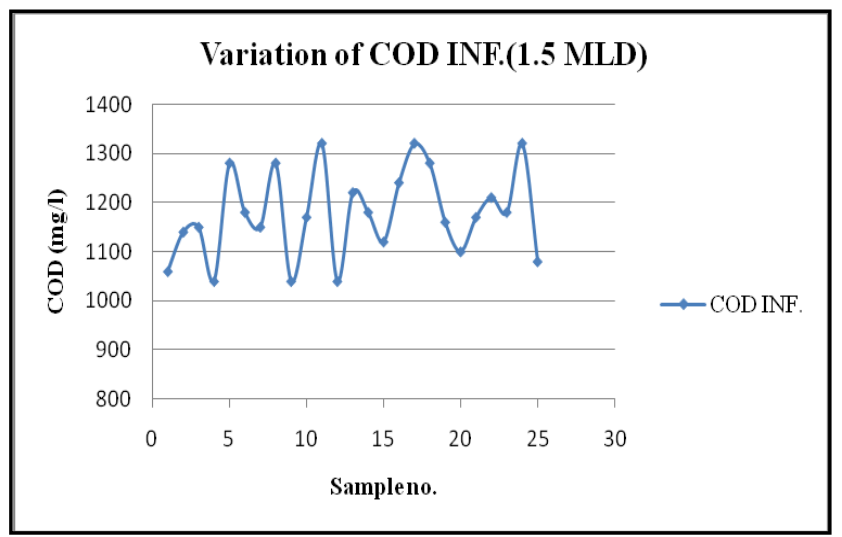

Fig.4.5: Variation of COD at influent in CETP

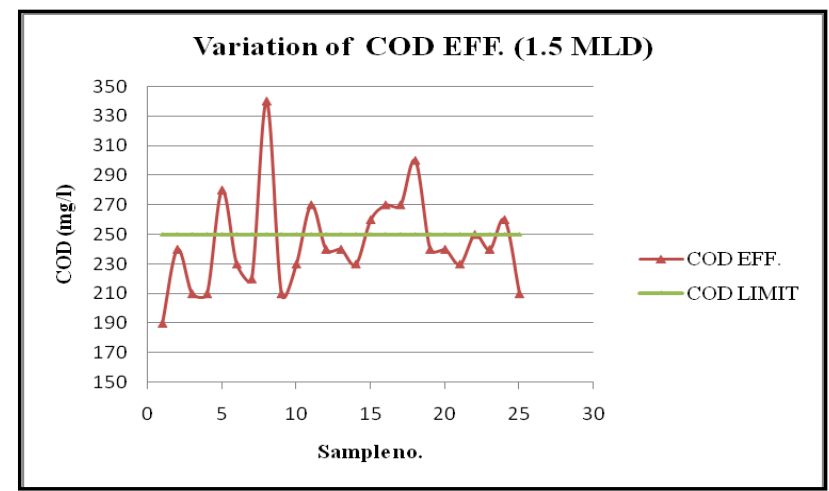

Fig.4.6: Variation of COD at effluent in CETP

\subsection{Comparison of results with CPCB Standards}

Following table is showing maximum, minimum and average values of parameters at the effluent of CETP during the study, percentage reduction after treatment and their comparison with CPCB standards. All values are in $\mathrm{mg} / \mathrm{l}$ except $\mathrm{pH}$.

Table 4.1: Dombivali CETP (1.5 MLD) effluent values.

\begin{tabular}{|l|l|l|l|l|l|l|}
\hline $\begin{array}{l}\text { Sr. } \\
\text { no. }\end{array}$ & Parameter & Max. Min. & Avg. & $\begin{array}{l}\text { Percent } \\
\text { removal }\end{array}$ & CPCB limit \\
\hline 1 & pH & 8.5 & 6.5 & 7.44 & - & 5.5 to 9.0 \\
\hline 2 & TSS & 160 & 30 & 78.8 & $79.81 \%$ & 100 \\
\hline 3 & TDS & 1800 & 710 & 1070.4 & $21.97 \%$ & 2100 \\
\hline 4 & BOD & 90 & 30 & 51.2 & $86.63 \%$ & 100 \\
\hline 5 & COD & 340 & 190 & 244.4 & $79.27 \%$ & 250 \\
\hline
\end{tabular}




\section{CONCLUSIONS}

The study indicates that all major pollutants were reduced in the wastewater after treatment. The $\mathrm{pH}, \mathrm{BOD}, \mathrm{COD}, \mathrm{TSS}$ and TDS at the influent were recorded to be $7.92,381 \mathrm{mg} / \mathrm{l}$, $1177.2 \mathrm{mg} / \mathrm{l}, 382.4 \mathrm{mg} / \mathrm{l}, 1368.4 \mathrm{mg} / \mathrm{l}$ for CETP. While the average values of the same parameters in the effluent were 7.12, 51.2mg/l, $244.4 \mathrm{mg} / \mathrm{l}, \quad 78.8 \mathrm{mg} / \mathrm{l}, \quad 1070.4 \mathrm{mg} / \mathrm{l}$ respectively. The BOD and COD values were reduced to much extent which shows the removal of organic content. The percentage removal of TDS was found to be comparatively low than other parameters. The study indicates that all major pollutants were reduced after the treatment and the effluent values for both CETPs were well within limit of discharge into the creek as per MPCB and CPCB standards. Hence study concludes, CETP under study is operated with the norms given by the MPCB and CPCB.

\section{REFERENCES}

[1] A.K.Biswas and S.N.Kaul, Prospects of common effluent treatment plants, 28th WEDC conference, sustainble environmental sanitation ans water services, Kolkata, India P.1-3 (2002).

[2] P.Govindswamy,S.D.Madhvan, S.Revathi and P. Shanmugum, Performance evaluation of common effluent treatment plant for tanneries at Pallavaram CETP, Journal of environ. Science and engg. vol.48, no.3, P.213-220,(2006).

[3] Sangeeth Aiyappa, Common effluent treatment plant technology and treatment processes: The alternative strategies, Svaraj,working paper series no.2, P.1-10.

[4] Samiya Ahmed,Alexandra,Clenett,Matthew Clark and Kelvin Tapley, Choosing an effuent treatment plant,Department for international development, Stockholm environment institute, P.1-33.

[5] Central Pollution Control Board, Performance status of common effluent treatment plants in India (2005).

[6] Metcalf and Eddy, Wastewater engineering treatment and reuse, Tata Mcgraw-Hill publishing company ltd., New Delhi (2003).

[7] Operating manual for Dombivali CETP.

[8] S.J.Arceivala, Wastewater treatment and pollution control, Tata McGraw-Hill publishing company ltd., New Delhi (1999).

[9] Andrew D. Eaton, Lenore S. Clesceri, Arnold E.Greenberq.: Standard Methods for Examination of Water and Wastewater, American Public Health Association, Washington, D.C. (1995).

[10] A.D.Patwardhan, Industrial waste water treatment (2008).

[11] Vinish Kathuria, Pollution Control By Small Scale Industries: Lessons from collective action failure in India.

[12] Egyptian Environmental Affairs Agency, Industrial waste water treatment plants, Inspection procedure manual (2002).

\section{BIOGRAPHIES}

Ketan A.Salunke, Assistant Professor, Department Civil Engineering Department Sandip Institute of Engineering \& Management, Trimbak Road, Mahiravani,Nashik 422003,India

E-mail Address: ketan.salunke11@gmail.com

Dr. Prashant P.Bhave, Associate Professor, Department Civil and Environmental Engineering, V.J. Technological Institute, Matunga, Mumbai 400019, India

E-mail Address: ppbhave@vjti.org.in

Manish D Mata, Lecturer MET BKC IOE, Nasik. Maharashtra, India.

E-mail Address: manishmata@gmail.com 